Sains Malaysiana 49(12)(2020): 3125-3143

http://dx.doi.org/10.17576/jsm-2020-4912-25

\title{
Modification and Optimization of Rice Husk Ash Bio-Filler in Sulfonated Polyimide Membrane for Direct Methanol Fuel Cell
}

(Pengubahsuaian dan Pengoptimuman Bio-Pengisi Abu Sekam Padi dalam Membran Poliimida Tersulfonan untuk Bahan Api Sel Metanol Langsung)

\author{
You Po Ying, Siti Kartom Kamarudin, Mohd Shahbudin Masdar \& AzRAn Mohd Zainoodin*
}

\begin{abstract}
Direct methanol fuel cell (DMFC) is a very high potential renewable and sustainable energy for portable devices as it has very high energy density and more environmentally friendly. Adding filler into the membrane matrix had reported in improved performance of the DMFC. However, addition of filler will lead to the decrease of the ion exchange capacity of the membrane, which will in turn reduce the fuel cell performance. Hence, this work studies the modification of rice husk ash via sulfonation process and the effect of the synthesis parameter of novel sulfonated polyimides/sulfonated rice husk ash (SPI/SRHA) composite membrane towards fuel cell performance where filler sRHA had been synthesized via the mixing reaction between rice husk ash (RHA) with chloroform and chlorosulfonic acid. The composition of filler in membranes was optimized with different synthesis parameters such as different types of filler used, loading of filler in membrane and membrane annealing temperature. Investigation of the effects for these three parameters on the physicochemical properties of the composite membranes produced was carried out using response surface methodology (RSM) approach to optimize the synthesis parameters of the composite membrane. The fillers and composite membranes were characterized by Fourier transform infrared spectroscopy, X-ray diffraction, Brunauer-Emmett-Teller (BET) analysis and transmission electron microscopy. Different synthesis parameters had shown different influences on the physicochemical properties of the composite membranes and consequently, gave different passive fuel cell performances of DMFCs too. The optimized membrane (S-12-sR) showed enhanced physicochemical performance as well as the passive single cell performance as compared to pure SPI and Nafion 117 membranes. The water uptake,

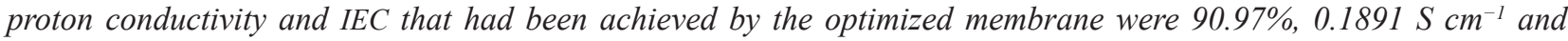
$0.2608 \mathrm{mmol} \mathrm{g}^{-1}$ respectively. The maximum power density of the passive DMFC was improved from $8.1 \mathrm{~mW} \mathrm{~cm}$ to $16.4 \mathrm{~mW} \mathrm{~cm}^{-2}$ under ambient conditions.
\end{abstract}

Keywords: Bio-filler; composite membrane; physicochemical; sulfonated polyimide; sulfonated rice husk ash

\section{ABSTRAK}

Bahan api sel metanol langsung (DMFC) adalah tenaga yang boleh diperbaharui dan lestari yang berpotensi tinggi untuk peranti mudah alih kerana mempunyai ketumpatan tenaga yang sangat tinggi dan lebih mesra alam. Penambahan pengisi ke dalam matriks membran telah dilaporkan mampu meningkatan prestasi DMFC. Walau bagaimanapun, penambahan pengisi akan menyebabkan penurunan kapasiti pertukaran ion membran, yang seterusnya akan mengurangkan prestasi bahan api sel. Oleh itu, kajian ini mengkaji pengubahsuaian abu sekam padi melalui proses sulfonasi dan kesan parameter sintesis membran komposit polimida sulfonasi/abu sekam padi sulfonasi (SPI/sRHA) terhadap prestasi bahan api sel dengan pengisi sRHA telah disintesis melalui pencampuran tindak balas antara abu sekam padi (RHA) dengan kloroform dan asid klorosulfonik. Komposisi pengisi dalam membran dioptimumkan dengan parameter sintesis yang berbeza seperti pelbagai jenis pengisi yang digunakan, pemuatan pengisi dalam membran dan suhu penyepuhlindapan membran. Kajian kesan ketiga-tiga parameter tersebut pada sifat fizikokimia membran komposit yang dihasilkan dilakukan menggunakan pendekatan kaedah respon permukaan (RSM) untuk mengoptimumkan parameter sintesis membran komposit. Pengisi dan membran komposit dicirikan dengan spektroskopi inframerah jelmaan Fourier, analisis pembelauan sinar-X, analisis Brunauer-Emmett-Teller (BET) dan mikroskop transmisi elektron. Parameter sintesis yang berbeza telah menunjukkan pengaruh yang berbeza pada sifat fizikokimia membran komposit dan akibatnya, juga memberikan prestasi bahan api sel DMFC pasif yang berbeza. Membran yang dioptimumkan (S-12-sR) menunjukkan peningkatan prestasi fizikokimia serta prestasi sel tunggal pasif berbanding dengan membran SPI dan Nafion 117 tulen. Kadar penyerapan air, kekonduksian proton dan IEC yang berjaya dicapai dengan pengoptimuman membran adalah $90.97 \%, 0.1891 \mathrm{~S} \mathrm{~cm}^{-1}$ dan $0.2608 \mathrm{mmol} \mathrm{g}^{-1}$. Ketumpatan kuasa maksimum DMFC pasif ditingkatkan dari $8.1 \mathrm{~mW} \mathrm{~cm}^{-2}$ menjadi $16.4 \mathrm{~mW} \mathrm{~cm}^{-2}$ dalam keadaan ambien.

Kata kunci: Abu sekam beras tersulfonan; bio-pengisi; fisikokimia; membran komposit; poliimida tersulfonan 


\section{INTRODUCTION}

Direct methanol fuel cells (DMFCs) have received high concern as the alternative renewable power sources due to the liquid-state alcohol used. The storage for liquid alcohol is more convenience than storage for gas-form fuel (i.e. hydrogen as a fuel in PEMFC) (Fadzillah et al. 2019; Ong et al. 2017a). Due to its liquid-form fuel, intense studies and researches have been done on DMFC with one of the aims to replace the current petrol operated vehicles to DMFC-functioned vehicles as both use the same state of fuel. However, current DMFCs are still facing some challenges that are required to be solved before it can be implemented in daily applications. The main problems in DMFC are the high rate of fuel crossover which leads to low fuel cell performance. Methanol crossover usually occurs when the anode side of methanol diffuses through the membrane and reaches the cathode side of the membrane electrode assembly (MEA). This occurrence will poison the catalyst used in the cathode side (usually platinum) as Pt is very easy to have carbon monoxide (CO) poisoning (Ekrami-Kakhki et al. 2019; Johánek et al. 2019; Zainoodin et al. 2014). The by-product (in this case is the $\mathrm{CO}$ ) produced when Pt in contact with methanol. This CO will clog the active surface of the platinum and hence reduce the activity rate of the $\mathrm{Pt}$. CO poisoning will lead to a drastic drop in fuel cell performance. Hence, many researchers have been carried out a series of research works in order to overcome this issue.

Implementation of an organic-inorganic combination of filler and membrane used in DMFC had improved not only the methanol crossover in DMFC (Liu et al. 2018; Parthiban et al. 2018) but also enhanced the physicochemical properties (water uptake, proton conductivity and ion exchange capacity) of the composite membrane itself (Abdullah \& Kamarudin 2015; Awang et al. 2018). The high performance of water uptake, proton conductivity and ion exchange capacity had led to enhanced fuel cell performance in terms of current and power density. Cui et al. (2018) had developed siliconaluminium oxide filler for Nafion-based composite membrane. They claimed that the addition of inorganic filler had increased 4 times the maximum power density of the composite membranes compared to the pristine Nafion membrane. Addition of inorganic filler was also reported to have improved in term of stability and durability of the fuel cell system (Saccà et al. 2018). Kuo and Lin (2018) proved that the incorporation of mesoporous silicate into polybenzimidazole polymer had significantly strengthened the composite membrane in terms of mechanical properties.

Silica $\left(\mathrm{SiO}_{2}\right)$ had been widely used as filler for the membrane in DMFC applications. Addition of silica into polymer matrix had enhanced the composite membranes in term of the physicochemical properties, fuel cell performance and also the durability of the fuel cell (Wang et al. 2018; Ying et al. 2018). Li et al. (2018) had discovered that more than $30 \%$ of fuel cell performance improvement can be achieved by adding functionalized silica into the Nafion membrane matrix. However, the synthesis of $\mathrm{SiO}_{2}$ usually involved a series of complicated reactions and the chemicals used to synthesize $\mathrm{SiO}_{2}$ were not environmental friendly. Hence, alternatives, which were rich in $\mathrm{SiO}_{2}$ and eco-friendly, had been focussed to replace synthetic silica.

Rice husk ash (RHA) is one of the silica-rich sources, which is abundant and easy to be produced. Approximate $90 \%$ or higher purity of silica can be obtained from RHA (Azat et al. 2019; Salim et al. 2018). It would be an advantage to implement RHA as filler for DMFC membranes that can give the same or better fuel cell performance as compared to synthetic silica. Till now, there is no work reported on using modified RHA as filler for membrane in DMFC application. In previous work (You et al. 2019), we had incorporated RHA as bio-filler in sulfonated polyimide (SPI) composite membranes for DMFC applications. It was proved that incorporating RHA into SPI matrix had significantly reduced the effect of methanol crossover and RHA was successfully improving the physicochemical properties of the composite membranes produced and fuel cell performance. However, the addition of RHA into SPI polymer matrix had reduced the ion exchange capacity of the composite membranes and this may bring a negative impact towards fuel cell performance. Hence, modifications on RHA filler had been done in this work with the main concern to improve the performance of IEC for the composite membranes fabricated and at the same time, improves the DMFC performance.

Thus, in this work, RHA had gone through sulfonation process and the produced sulfonated RHA (sRHA) was added into SPI polymer to form SPI/sRHA composite membrane. Here, the best combination of synthesis parameters and conditions for SPI/rice hush ash composite membrane were optimized using response surface methodology (RSM) which is an analysis method that proven will consumes less time, reduces the cost compared to full-factorial, provides the fewest/ reasonable experiments and also avoids bias of the factor effect in OFAT analysis (Shaari \& Kamarudin 2018). The relationship between the factors of the membrane synthesis parameters and the physicochemical properties as responses were studied. Lastly, passive single direct methanol fuel cell performance of the optimized composite membrane had been tested. 


\section{MATERIALS AND METHODS}

\section{MATERIALS}

Filler for the composite membrane, which was the rice husk, was taken from Satu Cita Sdn Bhd rice mill, which was located at Semanggol, Perak, Malaysia. Chemicals to synthesis the SPI polymer and the SPI-RHA composite membranes such as 1,4,5,8- naphthalenetetracarboxylic dianhydride (NTDA) (Sigma-Aldrich, Germany), 4,4-diaminodiphenyl ether (ODA) (Sigma-Aldrich, Germany), sodium hydroxide, concentrated hydrochloric acid, fuming sulfuric acid (SO3, 65\%) (Sigma-Aldrich, Germany), concentrated sulfuric acid (98\%), benzoic acid, acetone, dimethyl sulfoxide (DMSO) (SigmaAldrich, Germany) were used as received. Chemicals required for sulfonation of RHA such as chloroform and chlorosulfonic acid (Merck, Germany) were also used as received.

\section{EXPERIMENTAL METHODS SULFONATION REACTION PROCESS OF RHA}

$3.0 \mathrm{~g}$ of RHA, which had been produced under $2 \mathrm{~h} 600{ }^{\circ} \mathrm{C}$ oxidation, was mixed with $10 \mathrm{~mL}$ of chloroform in a 100 $\mathrm{mL}$ suction flask with a constant-pressure dropping funnel which was filled with $0.7 \mathrm{~mL}$ of chlorosulfonic acid. An inlet gas tube was equipped on the funnel as to conduct $\mathrm{HCl}$ gas produced into the water. The reaction mixture was stirred in an ice bath while chlorosulfonic acid was flow dropwise over $20 \mathrm{~min}$ into the flask. The mixture was stirred for an additional $2 \mathrm{~h}$ at room temperature after the addition was finished as to remove the remaining $\mathrm{HCl}$ gas. The mixture was washed with methanol and filtered. The solid residue was dried in an oven under $70{ }^{\circ} \mathrm{C}$ for 1 $\mathrm{h}$ to afford sulfonated RHA (sRHA) in powder form.

\section{SYNTHESIS OF RHA-SPI AND SRHA-SPI COMPOSITE MEMBRANES}

$1 \mathrm{~g}$ of SPI polymer was dissolved in $5 \mathrm{~mL}$ of DMSO. Another $5 \mathrm{~mL}$ of DMSO was added into different amount of filler (RHA or sRHA) ranging from $4-20 \mathrm{wt}$. \%. The filler was sonicated in ultrasonic cell crusher with power range $11 \%$ and 30 -second time interval for $5 \mathrm{~min}$. Then, the filler was mixed with SPI solution and sonicated for another $5 \mathrm{~min}$. The mixture was heated to $150{ }^{\circ} \mathrm{C}$ to completely dissolve the entire SPI polymer. The mixture was then solution-casted onto a petri dish and dried under $80{ }^{\circ} \mathrm{C}$ for $8 \mathrm{~h}$. The temperature was then raised to $150{ }^{\circ} \mathrm{C}$ and held for $2 \mathrm{~h}$ and another $8 \mathrm{~h}$ for different annealing temperature ranging from $156-184^{\circ} \mathrm{C}$.

\section{CHARACTERIZATION}

FUNCTIONAL GROUPS AND MORPHOLOGY ANALYSIS

Fourier transform infrared (FTIR) analysis was carried out using model Thermo Fisher Nicolet C700 (Thermo Scientific, USA). Each of the spectra was recorded at a $4 \mathrm{~cm}^{-1}$ resolution and 32 average scans were taken. The morphologies of the fillers were studied using Transmission Electron Microscope (TEM) using model Thermo Scientific ${ }^{\mathrm{TM}}$ Talos L120C (ThermoFisher Scientific, USA). The surface area and porosimetry (BrunauerEmmett-Teller, BET) analysis of RHA and sRHA were conducted using model Micromeritics ASAP 2020Plus (Micromeritics Instrument Corp., USA). Each filler was tested under two stages $\left(90{ }^{\circ} \mathrm{C}\right.$ for $60 \mathrm{~min}$ for pre-degas stage and $300^{\circ} \mathrm{C}$ for $60 \mathrm{~min}$ for degas stage).

\section{WATER UPTAKE AND ION EXCHANGE CAPACITY (IEC)}

Water uptake of the pure SPI, SPI/RHA and SPI/sRHA composite membranes were taken by immersing the membranes into deionized water for $24 \mathrm{~h}$. Then, the membranes were dried in a conventional oven. The weight of each membrane was recorded for every 30 min interval and the dry weight of the membrane was determined when the difference between the previous and last reading was less than $5 \%$. The water uptake of each membrane was calculated using (1):

$$
\text { Water Uptake }(W U)=\frac{W_{w e t}-W_{d r y}}{W_{\text {dry }}} \times 100 \%
$$

where $W_{\text {wet }}$ was the wet membrane weight; and $W_{d r y}$ was the dried membrane weight.

Ion exchange capacity (mmol of sulfonic acid per $g$ of sample) of the pure SPI, SPI/RHA and SPI/ sRHA composite membranes was determined by using the method of back titration. The membranes were first immersed in $1 \mathrm{M} \mathrm{NaCl}$ solution for $48 \mathrm{~h}$. This was to allow the exchange and convert of acid forms $\left(\mathrm{H}^{+}\right.$ions in the membrane) to sodium forms $\left(\mathrm{Na}^{+}\right.$ions in $\mathrm{NaCl}$ solution). The $\mathrm{H}^{+}$ions, which had been exchanged within the solution, were titrated using $0.005 \mathrm{M} \mathrm{NaOH}$ solution. Acid-base indicator, phenolphthalein was added to the solution and titration was stopped when the clear solution changed into light pink colour. The volume of $\mathrm{NaOH}$ used to neutralize the solution was recorded for each membrane. The ion exchange capacities of the membranes were calculated using the following equation:

$$
I E C=\frac{V_{\mathrm{NaOH}} \times C_{\mathrm{NaOH}}}{W_{d r y}}
$$

where $W_{d r y}$ was the dry sample weight in the $\mathrm{H}^{+}$form; $V_{\mathrm{NaOH}}$ was the titrated $\mathrm{NaOH}$ volume; and $C_{\mathrm{NaOH}}$ was the $\mathrm{NaOH}$ concentration used. 


\section{PROTON CONDUCTIVITY}

Proton conductivities of pure SPI, SPI/RHA and SPI/ sRHA composite membranes in full hydration form were measured in the lateral direction by $\mathrm{AC}$ impedance method using Multi-channel Potentiostat/Galvanostat (WonATech, Korea). Before carrying out the test, the ascast membranes were soaked in $2 \mathrm{M}$ methanol solution for $1 \mathrm{~h}$ at $60^{\circ} \mathrm{C}$ in order to remove the DMSO residue. Then, the membranes were immersed in $1.0 \mathrm{~N}$ hydrochloric acid for $12 \mathrm{~h}$ in room temperate. This was the proton exchange treatment step. Next, the membranes in proton form were then immersed in deionized water for $2 \mathrm{~h}$. Finally, a modified four-probe AC impedance method was used to measure the resistance within each of the composite membranes. The proton conductivity of the membranes was calculated from the following equation:

$$
\sigma=\frac{L}{R A}
$$

where $\sigma$ was the proton conductivity in $\mathrm{S} \mathrm{cm}^{-1} ; L$ was the two electrodes distance; $R$ was the membrane resistance; and $A$ was the membrane cross-sectional area.

\section{DMFC PASSIVE SINGLE CELL PERFORMANCE}

The membrane electrode assembly (MEA) for DMFC passive single cell performance was produced by hotpressing the composite membrane together with anode and cathode electrodes. A layer of Vulcan carbon was manually casted on the surface of carbon cloth as to act as a gas diffusion layer (GDL). Then, catalysts for the anode (PtRu with $8 \mathrm{mg} \mathrm{cm}^{-2}$ loading) and for the cathode
(Pt with $8 \mathrm{mg} \mathrm{cm}^{-2}$ loading) were manually casted on the surface of GDL as anode and cathode catalyst layers, respectively. DMFC passive single cell performance was tested in an air-breathing single cell where the active area for this cell was $2 \mathrm{~cm} \times 2 \mathrm{~cm}$. It had a built-in container that contained $10.5 \mathrm{~mL}$ methanol solution. A potentiostat (WonATech, USA) was used to obtain the polarization data. The voltage reaction where the load current was used for the fuel cell under room temperature and atmospheric pressure was measured. $2 \mathrm{M}$ methanol was used as fuel in an anodic container and surrounding air was diffused into the opened cathode surface.

\section{EXPERIMENTAL DESIGN}

In order to obtain the highest fuel cell membrane performance in terms of physicochemical properties, the synthesis parameters of the composite membrane were optimized using Central Composite Design (CCD), which was one of the methods in response surface methodology (RSM). For this work, three factors or independent variables such as loading of filler (A), annealing temperature (B) and type of filler (C) had been selected as the physicochemical properties of a membrane were highly dependent on the membrane synthesis parameters. At the beginning of the optimization, their effects towards the outputs of the optimization, which were the water uptake, proton conductivity and ion exchange capacity, and their interactions had been investigated based on RSM. The design of the experiment and responses were tabulated in Table 1. Each factor was varied at 5 levels as showed in Table 2.

TABLE 1. Design schedule and responses of the experiment

\begin{tabular}{|c|c|c|c|c|c|c|}
\hline Run & $\begin{array}{l}\text { A: Filler loading } \\
\quad \text { (wt.\%) }\end{array}$ & $\begin{array}{l}\text { B: Annealing } \\
\text { temperature }\left({ }^{\circ} \mathrm{C}\right)\end{array}$ & C: Filler type & Water uptake (\%) & $\begin{array}{c}\text { Proton } \\
\text { conductivity } \\
\left(\mathrm{S} \mathrm{cm}^{-1}\right)\end{array}$ & $\begin{array}{c}\text { IEC } \\
\left(\mathrm{mmol} \mathrm{g}^{-1}\right)\end{array}$ \\
\hline 1 & 10 & 170 & SRHA & 101.99 & 0.2027 & 0.2564 \\
\hline 2 & 10 & 170 & RHA & 85.54 & 0.1678 & 0.2156 \\
\hline 3 & 20 & 160 & sRHA & 89.48 & 0.1678 & 0.2300 \\
\hline 4 & 20 & 180 & RHA & 83.33 & 0.1592 & 0.2179 \\
\hline 5 & 10 & 170 & RHA & 85.10 & 0.1640 & 0.2209 \\
\hline 6 & 20 & 180 & sRHA & 91.50 & 0.1678 & 0.2171 \\
\hline 7 & 4 & 170 & sRHA & 80.13 & 0.1656 & 0.2785 \\
\hline 8 & 0 & 180 & RHA & 74.87 & 0.1406 & 0.2657 \\
\hline 9 & 0 & 160 & sRHA & 56.71 & 0.1062 & 0.2508 \\
\hline 10 & 0 & 180 & SRHA & 74.87 & 0.1406 & 0.2657 \\
\hline 11 & 10 & 170 & RHA & 90.26 & 0.1790 & 0.2350 \\
\hline 12 & 10 & 156 & RHA & 77.22 & 0.1347 & 0.2286 \\
\hline 13 & 24 & 170 & RHA & 84.12 & 0.1227 & 0.1958 \\
\hline
\end{tabular}




\begin{tabular}{lllllll}
14 & 10 & 170 & sRHA & 96.78 & 0.1897 & 0.2564 \\
15 & 10 & 184 & sRHA & 90.24 & 0.1897 & 0.2667 \\
16 & 10 & 156 & sRHA & 77.22 & 0.1636 & 0.2662 \\
17 & 20 & 160 & RHA & 77.22 & 0.1522 & 0.2252 \\
18 & 0 & 160 & RHA & 56.71 & 0.1062 & 0.2508 \\
19 & 10 & 170 & sRHA & 97.00 & 0.1866 & 0.2564 \\
20 & 10 & 170 & RHA & 87.35 & 0.1816 & 0.2512 \\
21 & 10 & 170 & RHA & 84.97 & 0.1665 & 0.2554 \\
22 & 10 & 170 & sRHA & 92.45 & 0.1937 & 0.2564 \\
23 & 10 & 184 & RHA & 83.55 & 0.1665 & 0.2552 \\
24 & 10 & 170 & sRHA & 95.31 & 0.1837 & 0.2564 \\
25 & 4 & 170 & RHA & 74.87 & 0.1558 & 0.2414 \\
26 & 24 & 170 & sRHA & 91.05 & 0.1671 & 0.2533 \\
\hline
\end{tabular}

TABLE 2. The levels of independent variables in the experiments based on central composite design (CCD)

\begin{tabular}{lccccc}
\hline \multirow{2}{*}{ Independent variables } & \multicolumn{5}{c}{ Symbol coded level } \\
\cline { 2 - 5 } & $\alpha=-1.41421$ & -1 & 0 & 1 & $\alpha=1.41421$ \\
\hline Filler loading (A) & -4.14214 & 0 & 10 & 20 & 24.142 \\
Annealing temperature (B) & 155.858 & 160 & 170 & 180 & 184.14 \\
Filler type (C) & - & - & RHA & sRHA & - \\
\hline
\end{tabular}

\section{RESULTS AND DISCUSSION}

STRUCTURE OF SYNTHESIZED SULFONATED RHA FILLER FTIR ANALYSIS

Figure 1 displayed the FTIR spectra for the two types of filler, which were the RHA and sRHA, respectively. There were two obvious most intense adsorption peaks that were located at 797 and $1043 \mathrm{~cm}^{-1}$ for RHA whereas for sRHA, they were located at 800 and $1083 \mathrm{~cm}^{-1}$, respectively. For RHA, the absorption at $797 \mathrm{~cm}^{-1}$ showed that it was the ring-structured tetrahedral $\mathrm{SiO} 4$, which it also represented the Si-O-Si symmetric stretching. The band at 1043 $\mathrm{cm}^{-1}$ for RHA was the characteristic of the asymmetric stretching mode of the Si-O-Si bonds. The absorption

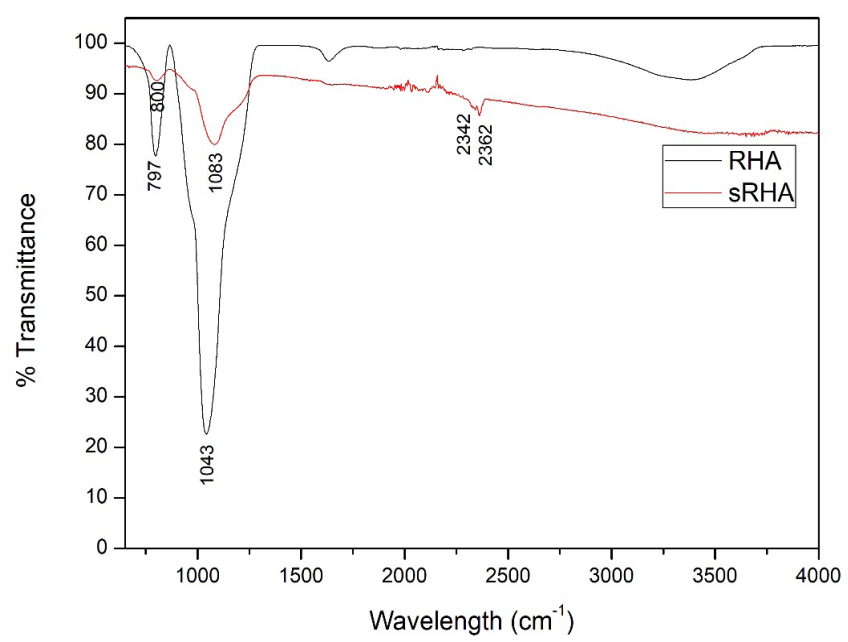

FIGURE 1. FTIR spectra of RHA and sRHA 
peaks at 1631 and $3383 \mathrm{~cm}^{-1}$ were associated with the water molecules stretching and bending modes. The infrared spectrum of sRHA displayed remarkable differences. For instance, the peak at $800 \mathrm{~cm}^{-1}$ represented the symmetric SiO4 stretching vibration and the strong peak at 1083 $\mathrm{cm}^{-1}$ corresponded to the asymmetric vibration of Si-O$\mathrm{Si}$. The intermolecular hydrogen bonds that showed at the range of 2100 to $2900 \mathrm{~cm}^{-1}$ and broader $\mathrm{H}_{2} \mathrm{O}$ bonds at $3400 \mathrm{~cm}^{-1}$ indicated the $-\mathrm{SiOH}$ and $-\mathrm{O}-\mathrm{SO}_{3} \mathrm{H}$ groups of $\mathrm{SiO}_{2}-\mathrm{SO}_{3} \mathrm{H}$ with additional hydrogen bonds from water molecules (Barbosa et al. 2018).

\section{BET AND MORPHOLOGY ANALYSIS}

Table 3 summarized the BET surface area, the volume of the pore and the average pore size for the two types of filler: RHA and SRHA. The BET surface area was calculated from the plots of BET with the P/P0 value of 0.20. From Table 3, it showed that RHA had greater BET surface area, higher pore volume and approximately similar pore size as compared to sRHA (4.33 and 4.96\% higher in BET surface area and pore volume, respectively). It can be deduced that sulfonation on the rice husk ash had slightly reduced the BET surface area and the pore volume as $\mathrm{SO} 3$ particles had been incorporated into the rice husk ash. The average pore size diameter of $5 \mathrm{~nm}$ indicated that the RHA and SRHA formed were mesoporous (IUPAC: $2-50 \mathrm{~nm}=$ mesoporous).

TABLE 3. BET analysis of fillers RHA and sRHA

\begin{tabular}{lccc}
\hline Filler & BETarea & Pore volume & Average pore size \\
\hline & $\left(\mathrm{m}^{2} / \mathrm{g}\right)$ & $\left(\mathrm{cm}^{3} / \mathrm{g}\right)$ & $(\mathrm{nm})$ \\
RHA & 275.95 & 0.3490 & 5.0591 \\
SRHA & 264.01 & 0.3317 & 5.0254 \\
\hline
\end{tabular}

Figure 2 represented the TEM images for fillers RHA and sRHA, respectively. Both displayed nearly spherical in shape of silica nanoparticles with an average diameter of about $50 \mathrm{~nm}$ were formed. For the RHA, there were some darker spots present in RHA where this meant they were the overlapped RHA particles. On the other hand, based on Figure 2, it was noticeable that there were a lot of dark spots present in SRHA as compared to RHA. The dark spots present in sRHA were the consequence of the sulfonation process. This verified that the SO3 molecules were added to the rice husk ash.

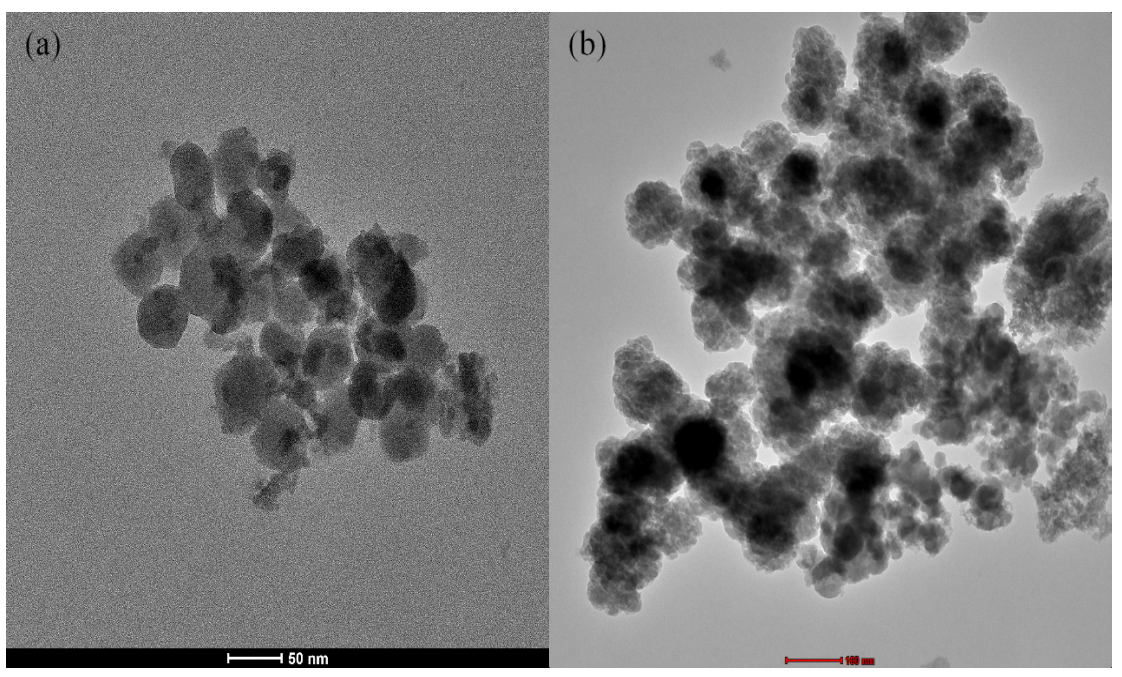

FIGURE 2. TEM images of (a) RHA (b) SRHA 


\section{PRIMARY PERFORMANCE}

Primary performance of the composite membrane produced was based on the analysis of membranes' water uptake ability, level of proton conductivity and the ion exchange capacity. A well-perform DMFC membrane mainly has the physicochemical properties of high water uptake, high proton conductivity and high ion exchange capacity. High water uptake leads to higher mobility for the proton to be transported in the membrane and hence produces low resistance. High proton conductivity gives higher rate of proton being transferred across the membrane. High ion exchange capacity will give more ions to be exchanged with the proton at the anode side. These will then lead to a higher fuel cell performance of DMFC.

Figure 3 gave the comparison of performance for the SPI/sRHA and SPI/RHA composite membranes with different loading of filler used. Using different types of RHA (pure RHA and sulfonated RHA) and filler contents in composite membranes had significantly affected the membrane performance. From Figure 3(a), sRHA gave better membrane performance in terms of water uptake and proton conductivity compared to RHA. This was mainly due to the presence of sulfonic acid groups in sRHA. The sulfonic acid group had improved the water retention of SPI/sRHA composite membranes (due to the greater water uptake capacity of the sulfonic acid group itself). On the other hands, proton conductivity of SPI/ sRHA membranes was higher as compared to SPI/RHA membranes. The sulfonic acid groups in SPI and sRHA act as the donor and acceptor for the proton carrier sites. Since SPI/sRHA membranes had more sulfonic acid groups compared to SPI/RHA membranes, hence, more proton carrier sites were available for SPI/sRHA membranes. Due to this, SPI/sRHA showed higher proton conductivity compared to SPI/RHA membranes. Both sRHA and RHA filler loading had shown the same trend towards the water uptake and proton conductivity with the values obtained by SPI/sRHA membranes were slightly higher than that of SPI/RHA membranes. This indicated that when the filler loading reached optimum value (both cases $10 \mathrm{wt} . \%$ ), the water uptake and proton conductivity for both composite membranes started to decrease. This may due to the higher rate of filler agglomeration when the filler loading exceeded 10 wt. $\%$.

Incorporation of sRHA into SPI membrane matrix had increased the performance of IEC in the composite membranes as shown in Figure 3(b). The highest value obtained by $10 \%$ filler loading SPI/sRHA membrane was $0.2785 \mathrm{mmol} \mathrm{g}^{-1}$, which was $15.4 \%$ higher than SPI/RHA membrane with the same amount of filler loading. IEC was defined as the number of sulfonic acid groups (unit: mmol) per $1 \mathrm{~g}$ of membrane. Hence, higher content of sulfonic acid groups present in SRHA had led to the increment of IEC in the composite membrane. Without sulfonation of RHA, further addition of RHA into SPI membrane matrix had reduced the IEC of the composite membranes produced.
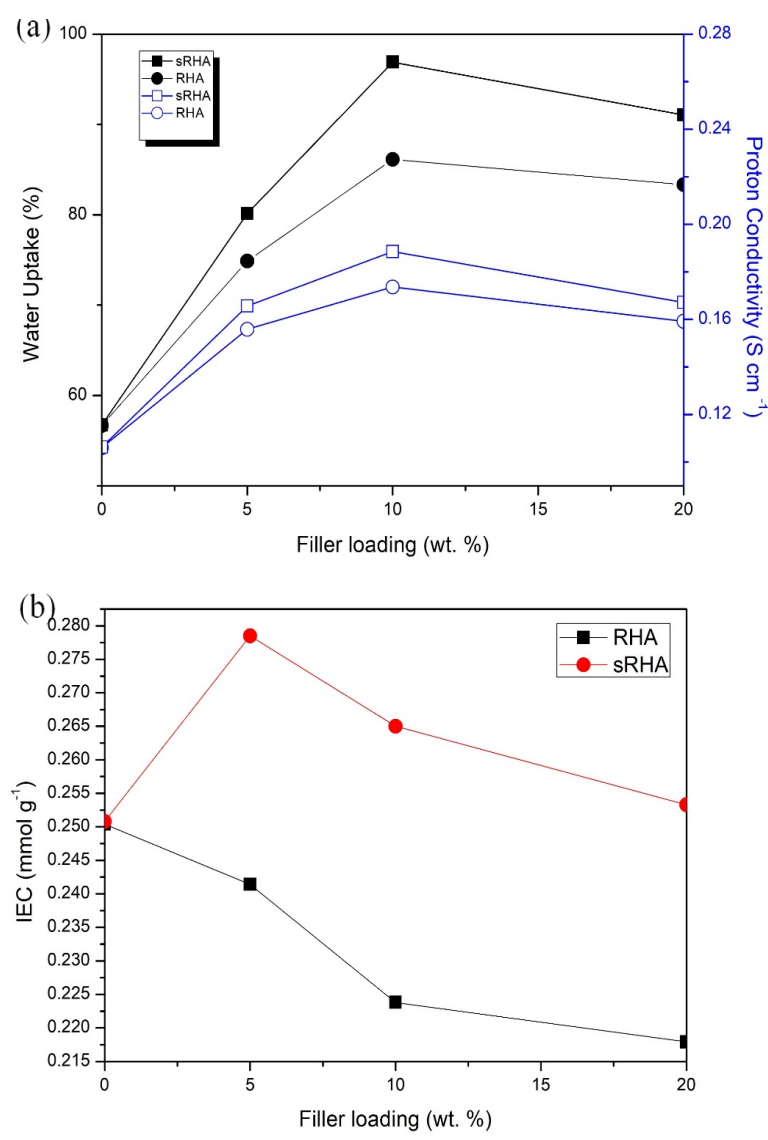

FIGURE 3. (a) Water uptake and proton conductivity and (b) ion exchange capacity of SPI/sRHA membranes and SPI/RHA membranes with different loading of filler 


\section{OPTIMIZATION BY RSM ANALYSIS}

A total of 26 different combinations of membrane synthesis parameters such as loading of filler (A), annealing temperature (B) and type of filler (C) were randomly derived. 13 runs in which 5 runs at the central point were conducted for two numerical factors (A and B) and another 13 runs for another categorical factor (C). The data were then fitted into the below second order polynomial equation.

$$
\eta=\beta_{0}+\sum_{j=1}^{k} \beta_{j} x_{j}+\sum_{j=1}^{k} \beta_{j j} x_{j}^{2}+\sum i \sum_{<j=2} \beta_{i j} x_{i} x_{j}+\varepsilon
$$

where $\eta$ was the predicted response; $\beta_{0}$ was the constant coefficients; $\beta_{i j} \beta_{i j}$ and $\beta_{i j}$ symbols were the coefficients for linear, quadratic and second order interaction effects, respectively. and were the coded independent parameter variable and were the standard error between the observed and calculated value.

Analysis of variance (ANOVA) was used to justify the adequacy of the response surface quadratic model for the composite membranes. Table 4(a)-4(c) summarized the conversion quadric model of the ANOVA. The obtained results were fitted using the least square regression. The regression model showed a successful correlation among the three factors as it provided an accurate description of the experimental data. The parameter F-value, p-value, lack of fit and R2 were used to investigate how well the given model fit the experimental data.

\section{ANOVA FOR RESPONSE SURFACE QUADRATIC MODEL OF PHYSICOCHEMICAL PROPERTIES}

The regression model was considered as statistically significant under two conditions in ANOVA: (1) when the p-value for the model was less than 0.0001 and (2) lack of fit showed that it was not statistically significant at $99 \%$ level of confidence. By giving these results, it can be said that the response equations were suitable to proceed with the CCD experiment. From Table 4(a)-4(c), the F-values of the model for water uptake, proton conductivity and ion exchange capacity were $29.3,32.61$, and 11.85 , respectively. The $p$-values for these three models were less than 0.0001 . This indicated that there was only $0.01 \%$ where the models were due to the noise. These implied that the models given were significant for the responses (physicochemical properties of composite membranes produced). In addition to that, the non-statistically significant of F-value for each lack of fit (1.74, 0.92, and 1.23 , respectively) demonstrated that these models were in a good fit. Hence, these results advocated that these models can be used to estimate the experimental data within the given range region.

TABLE 4. (a) ANOVA for water uptake, (b) ANOVA for proton conductivity and (c) ANOVA for IEC

\begin{tabular}{|c|c|c|c|c|c|c|}
\hline Source & Sum of squares & $\mathrm{df}$ & Mean square & F value & \multicolumn{2}{|c|}{ p-value $($ Prob > F) } \\
\hline Model & 2776.45 & 8 & 347.06 & 29.3 & $<0.0001$ & Significant \\
\hline A-Filler Loading & 1240 & 1 & 1240 & 104.69 & $<0.0001$ & \\
\hline B-Annealing Temperature & 323.25 & 1 & 323.25 & 27.29 & $<0.0001$ & \\
\hline C-Filler Type & 287.98 & 1 & 287.98 & 24.31 & 0.0001 & \\
\hline $\mathrm{AB}$ & 99.44 & 1 & 99.44 & 8.4 & 0.0100 & \\
\hline $\mathrm{AC}$ & 36.73 & 1 & 36.73 & 3.1 & 0.0962 & \\
\hline $\mathrm{BC}$ & 1.75 & 1 & 1.75 & 0.15 & 0.7058 & \\
\hline A2 & 879.06 & 1 & 879.06 & 74.22 & $<0.0001$ & \\
\hline B2 & 318.37 & 1 & 318.37 & 26.88 & $<0.0001$ & \\
\hline Residual & 201.35 & 17 & 11.84 & & & \\
\hline Lack of fit & 133.29 & 9 & 14.81 & 1.74 & 0.2234 & Not significant \\
\hline Pure error & 68.07 & 8 & 8.51 & & & \\
\hline Total correlation & 2977.8 & 25 & & & & \\
\hline Standard deviation & 3.25 & & & & $\mathrm{R} 2$ & 0.9504 \\
\hline Mean & 83.84 & & & & Adjusted R2 & 0.9114 \\
\hline
\end{tabular}


(b)

\begin{tabular}{|c|c|c|c|c|c|c|}
\hline Model & 0.015 & 8 & $1.84 \mathrm{E}-03$ & 32.61 & $<0.0001$ & Significant \\
\hline A-Filler Loading & $3.58 \mathrm{E}-03$ & 1 & $3.58 \mathrm{E}-03$ & 63.32 & $<0.0001$ & \\
\hline B-Annealing Temperature & $1.55 \mathrm{E}-03$ & 1 & $1.55 \mathrm{E}-03$ & 27.46 & $<0.0001$ & \\
\hline C-Filler Type & $1.84 \mathrm{E}-03$ & 1 & $1.84 \mathrm{E}-03$ & 32.54 & $<0.0001$ & \\
\hline $\mathrm{AB}$ & $4.76 \mathrm{E}-04$ & 1 & $4.76 \mathrm{E}-04$ & 8.42 & 0.0099 & \\
\hline $\mathrm{AC}$ & $3.50 \mathrm{E}-04$ & 1 & $3.50 \mathrm{E}-04$ & 6.2 & 0.0234 & \\
\hline $\mathrm{BC}$ & $1.42 \mathrm{E}-05$ & 1 & $1.42 \mathrm{E}-05$ & 0.25 & 0.6223 & \\
\hline A2 & $8.00 \mathrm{E}-03$ & 1 & $8.00 \mathrm{E}-03$ & 141.68 & $<0.0001$ & \\
\hline B2 & $1.06 \mathrm{E}-03$ & 1 & $1.06 \mathrm{E}-03$ & 18.82 & 0.0004 & \\
\hline Residual & $9.60 \mathrm{E}-04$ & 17 & $5.65 \mathrm{E}-05$ & & & \\
\hline Lack of fit & $4.89 \mathrm{E}-04$ & 9 & $5.43 \mathrm{E}-05$ & 0.92 & 0.5518 & Not significant \\
\hline Pure error & $4.72 \mathrm{E}-04$ & 8 & $5.90 \mathrm{E}-05$ & & & \\
\hline Total correlation & 0.016 & 25 & & & & \\
\hline Standard deviation & 0.0075161 & & & & $\mathrm{R} 2$ & 0.9388 \\
\hline Mean & 0.16 & & & & Adjusted R2 & 0.91 \\
\hline \multicolumn{7}{|l|}{ (c) } \\
\hline Model & 0.64 & 3 & 0.21 & 11.85 & $<0.0001$ & Significant \\
\hline A-Filler Loading & 0.38 & 1 & 0.38 & 21.17 & 0.0001 & \\
\hline B-Annealing Temperature & 0.014 & 1 & 0.014 & 0.79 & 0.3823 & \\
\hline C-Filler Type & 0.24 & 1 & 0.24 & 13.58 & 0.0013 & \\
\hline Residual & 0.39 & 22 & 0.018 & & & \\
\hline Lack of fit & 0.27 & 14 & 0.019 & 1.23 & 0.3958 & Not significant \\
\hline Pure error & 0.12 & 8 & 0.016 & & & \\
\hline Total correlation & 1.03 & 25 & & & & \\
\hline Standard deviation & 0.13 & & & & $\mathrm{R} 2$ & 0.6177 \\
\hline Mean & 2.45 & & & & Adjusted R2 & 0.5655 \\
\hline
\end{tabular}

From the ANOVA analysis, it gave that the adequate precision in the quadratic model for water uptake, proton conductivity, and IEC responses were 19.079, 19.994, and 12.205 , respectively, which had been shown in Table 5. These values meant adequate signal for the responses, where in this case were the physicochemical properties. These models showed high R2 values of 93.24\% for water uptake, $93.88 \%$ for proton conductivity and low value of $61.77 \%$ for IEC. The fit of the models was dominated by the coefficient of determination, R2. For IEC, the R2 value indicated that only $61.77 \%$ of IEC experimental data fitted to the model. However, even noisy, high-variability IEC data had a significant trend, which indicated that the predictor variables still provided information about the response even though data points fell further from the regression line for that model. The values of R2 and adjusted R2 showed for water uptake and proton conductivity were close to 1.0 . These high values advocated a high correlation between the observed values and the predicted values. This indicated that the regression model provided a very good explanation of the relationship between the independent variables and the responses. 
TABLE 5. Regression coefficients of physicochemical properties for composite membranes

\begin{tabular}{lcccccc}
\hline Kinetic parameters & Std. Dev. & Mean & R2 & Adj. R2 & Pred R2 & Adeq precision \\
\hline Water uptake & 3.44 & 83.84 & 0.9324 & 0.9006 & 0.8273 & 19.079 \\
Proton conductivity & 0.0075 & 0.16 & 0.9388 & 0.9100 & 0.8354 & 19.994 \\
Ion exchange capacity & 0.013 & 0.24 & 0.6177 & 0.5655 & 0.4395 & 12.205 \\
\hline
\end{tabular}

\section{DIAGNOSTIC OF PHYSICOCHEMICAL RESPONSES}

The diagnostic plots given in Figure 4 were used for estimating the adequacy of the regression model. The percentage value of actual physicochemical responses was the experimental result for a specific run whereas the predicted value was evaluated via the CCD model from the three independent variables. In Figure 4, it can be observed that there was a tendency in the linear regression fit. It proved that the model clarified the experimental range studied for response water uptake and proton conductivity. However, as for the response of IEC, the experimental data were distributed scattering far around the linear regression line, which had been explained by the low $\mathrm{R} 2$ value of 0.6177 that $61.77 \%$ of data were fitted to the model regression line.

A normal distribution function was then fitted to the studentized residuals. Figure 5 indicated the normal plot for the studentized residuals. From Figure 5, it shows the normal distribution of studentized residuals regarding S-shaped curve was not formed. The data points indicated that neither response transformation was required nor there was an apparent problem with normalization.

Figure 6 shows the studentized residual and predicted physicochemical responses of the composite membranes. The random scatter of the residuals in Figure 6 indicated that the suggested models were in the appropriate description of the process. Besides, the red lines in Figure 6 were the outlier $t$ plot for the three responses. It measured how many standard deviations of the actual values deviated from the predicted value. Most of the standard residuals should lie in the interval of \pm 3.00 . In Figure 6, there were no data beyond the interval 3 , which showed that the fitted models were consistent with all the data with no recording error.
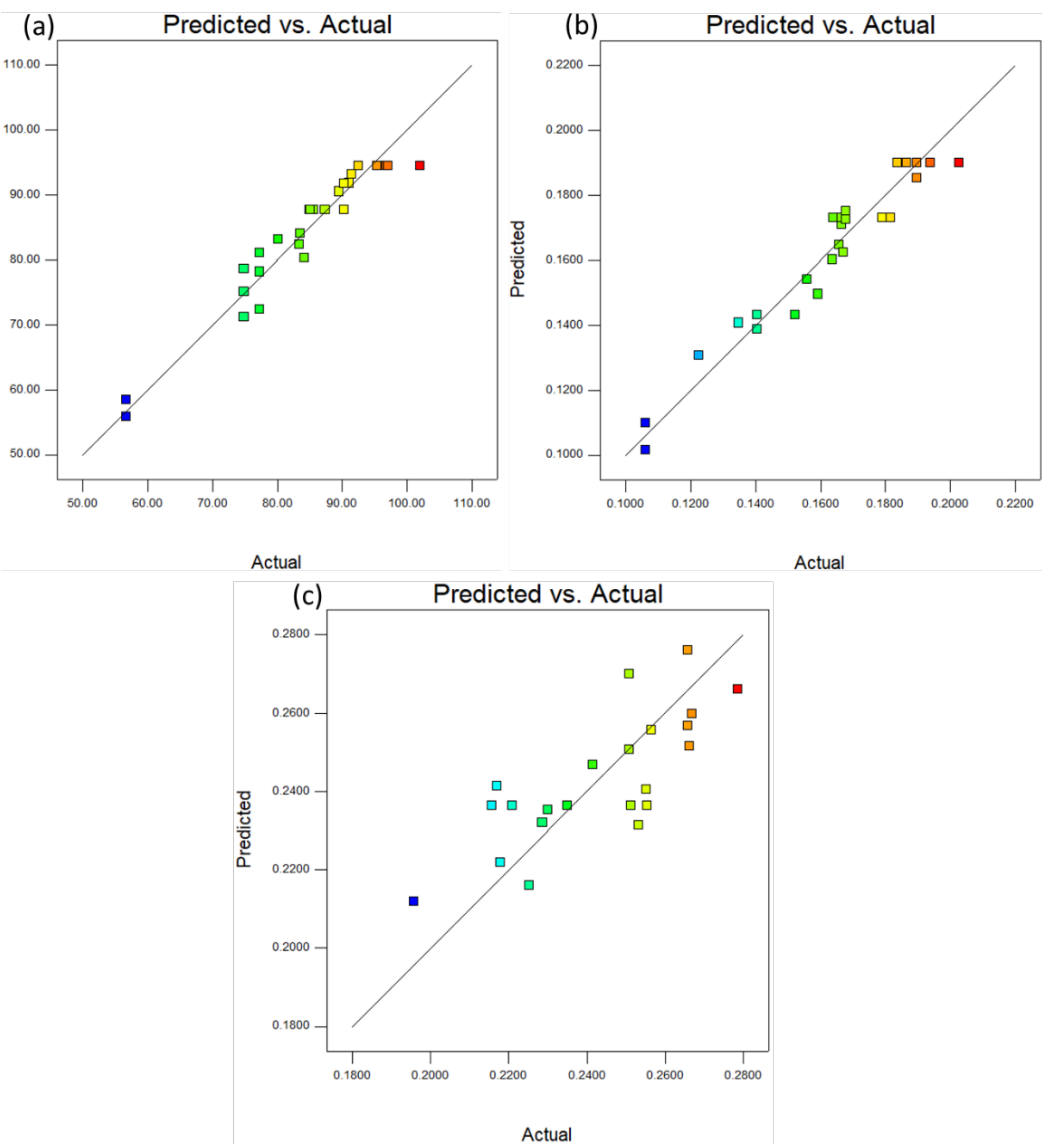

FIGURE 4. Observed responses (a) water uptake, (b) proton conductivity and (c) IEC predicted by the model equation versus experimentally obtained responses 

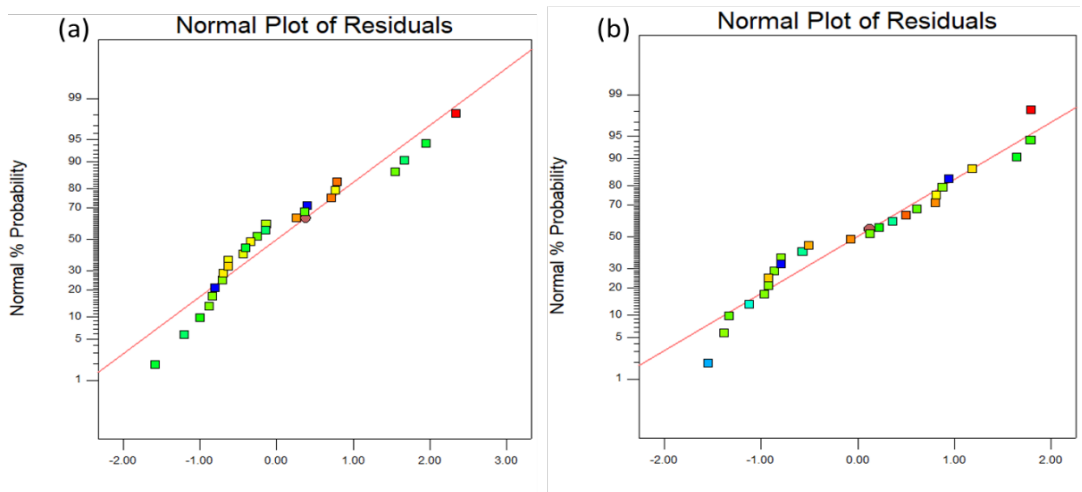

Internally Studentized Residuals

Internally Studentized Residuals

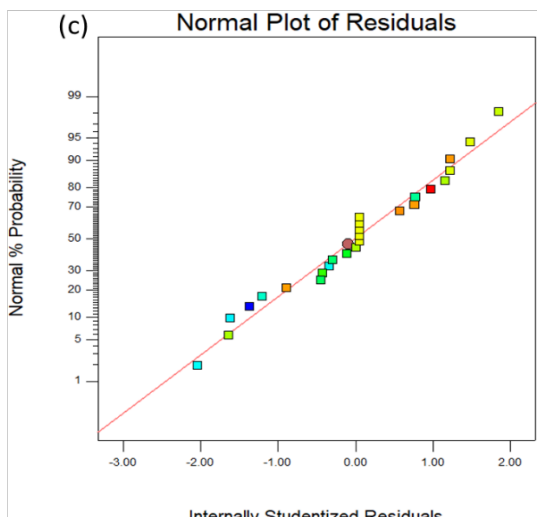

FIGURE 5. Normal \% probability versus observed current residuals of (a) water uptake, (b) proton conductivity and (c) IEC
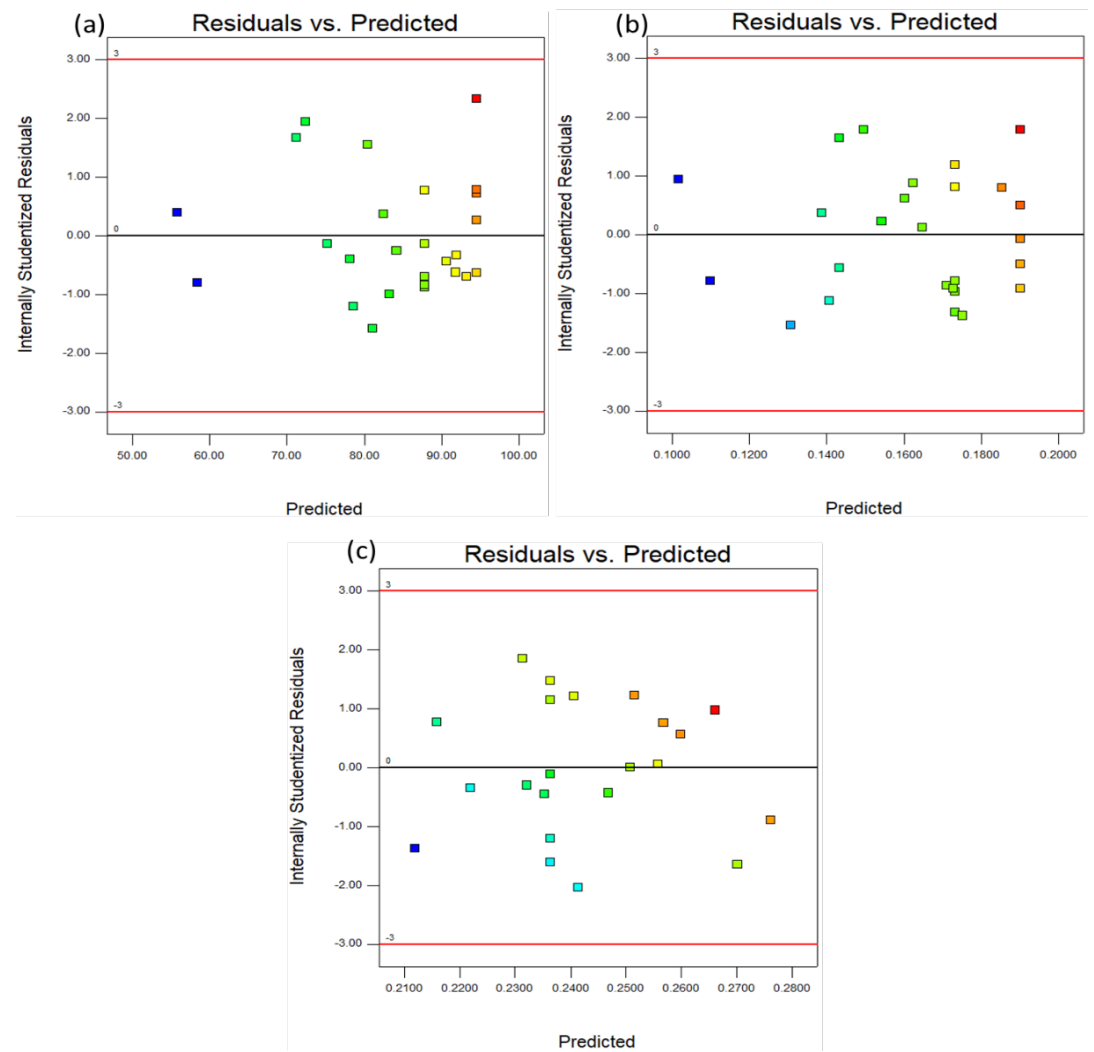

FIGURE 6. Studentized residuals versus predicted observed response of (a) water uptake, (b) proton conductivity and (c) IEC 


\section{FINAL EQUATION IN TERMS OF CODED FACTORS}

The least squares regression was employed to generate the full quadratic experimental models to predict water uptake model in terms of coded factors as given in (4).
Referring to the same evaluation as water uptake, the values for proton conductivity and IEC were as shown in Table 6.

TABLE 6. The equations of physicochemical responses

\begin{tabular}{lccc}
\hline & Water uptake $(\%)$ & Proton conductivity $\left(\mathrm{S} \mathrm{cm}^{-1}\right)$ & IEC $\left(\mathrm{mmol} \mathrm{g}^{-1}\right)$ \\
\hline & 91.12 & 0.1800 & 0.2500 \\
$* \mathrm{~A}$ & 10.82 & 0.0180 & -0.0170 \\
$* \mathrm{~B}$ & 4.52 & 0.0099 & 0.0030 \\
$* \mathrm{C}$ & 3.32 & 0.0084 & 0.0097 \\
$* \mathrm{AB}$ & -3.53 & -0.0077 & 0 \\
$* \mathrm{AC}$ & 1.71 & 0.0053 & 0 \\
$* \mathrm{BC}$ & 0.33 & -0.0009 & 0 \\
$* \mathrm{~A} 2$ & -10.29 & -0.0310 & 0 \\
$* \mathrm{~B} 2$ & -4.84 & -0.0088 & 0 \\
\hline
\end{tabular}

The least square regression was employed to generate the full quadratic experimental models to predict response models in terms of coded factors as shown in (5) to (7):

$($ Water uptake $)=91.12+10.82 A+4.52 B+3.32 C-3.53 A B$

$+1.71 A C+0.33 B C-10.29 A^{2}-4.84 B^{2}$

$($ Proton conductivity $)=0.1800+0.0180 A+0.0099 B+$ $0.0084 C-0.0077 A B+0.0053 A C-0.0009 B C-0.0310 A^{2}$ $-0.0088 B^{2}$

\section{$(I E C)=0.2500-0.0170 \mathrm{~A}+0.0030 \mathrm{~B}+0.0097 \mathrm{C}$}

where A, B, and C were stood for filler loading, annealing temperature and type of the filler, respectively. The sign in front of terms (either in positive or negative) showed synergistic effect (for positive) or antagonistic effect (for negative) in which these would indicate the influence of independent variables on the response.

\section{INTERACTIONS OF SYNTHESIS PARAMETERS AND OPTIMIZATION}

To understand the impact of each variable, three dimensional (3D) plots were made for the estimated responses to investigate the interactive effect among the three factors on the physicochemical properties within the experimental ranges as shown in Figures 7-9. The interactions between the parameters were demonstrated clearly by plotting two numeric variables (A and $\mathrm{B}$ ) with conversion on a 3D surface and a contour (2D) plot for each categorical variable (C).

\section{EFFECTS OF FACTORS ON WATER UPTAKE}

In Figure 7, at the same annealing temperature, by increasing filler loading in the membrane polymer matrix, the water uptake increased significantly from 10 to 15 wt. \% first until it reached maximum performance. Then, it gradually decreased when the filler loading increased from 15 to 20 wt. \%. Comparing both $2 \mathrm{D}$ contour plots, it showed that filler sRHA had higher potential to retain water in the composite membranes compared to filler RHA. This was due to the hydrophilic properties of the sulfonic group that presented in sRHA. Higher loading of sRHA meant more additional sulfonic group present in SPI matrix. Hence, water uptake increased. The annealing temperature had a less impact on the water uptake compared to the effect of filler loading. At constant filler loading, water uptake of the composite membranes 
increased with increased annealing temperature from 160 to $175^{\circ} \mathrm{C}$. When the annealing temperature exceeded 175 ${ }^{\circ} \mathrm{C}$, the water uptake of the composite membrane started to drop. At $175^{\circ} \mathrm{C}$, it was assumed that this temperature was the best parameter to remove internal stresses and toughen the composite membranes. The temperature that exceeded $175^{\circ} \mathrm{C}$ had caused the early starting of denatured and brittle formation of SPI polymer in the composite membranes. This led to a bad performance in water retention ability of composite membranes produced.
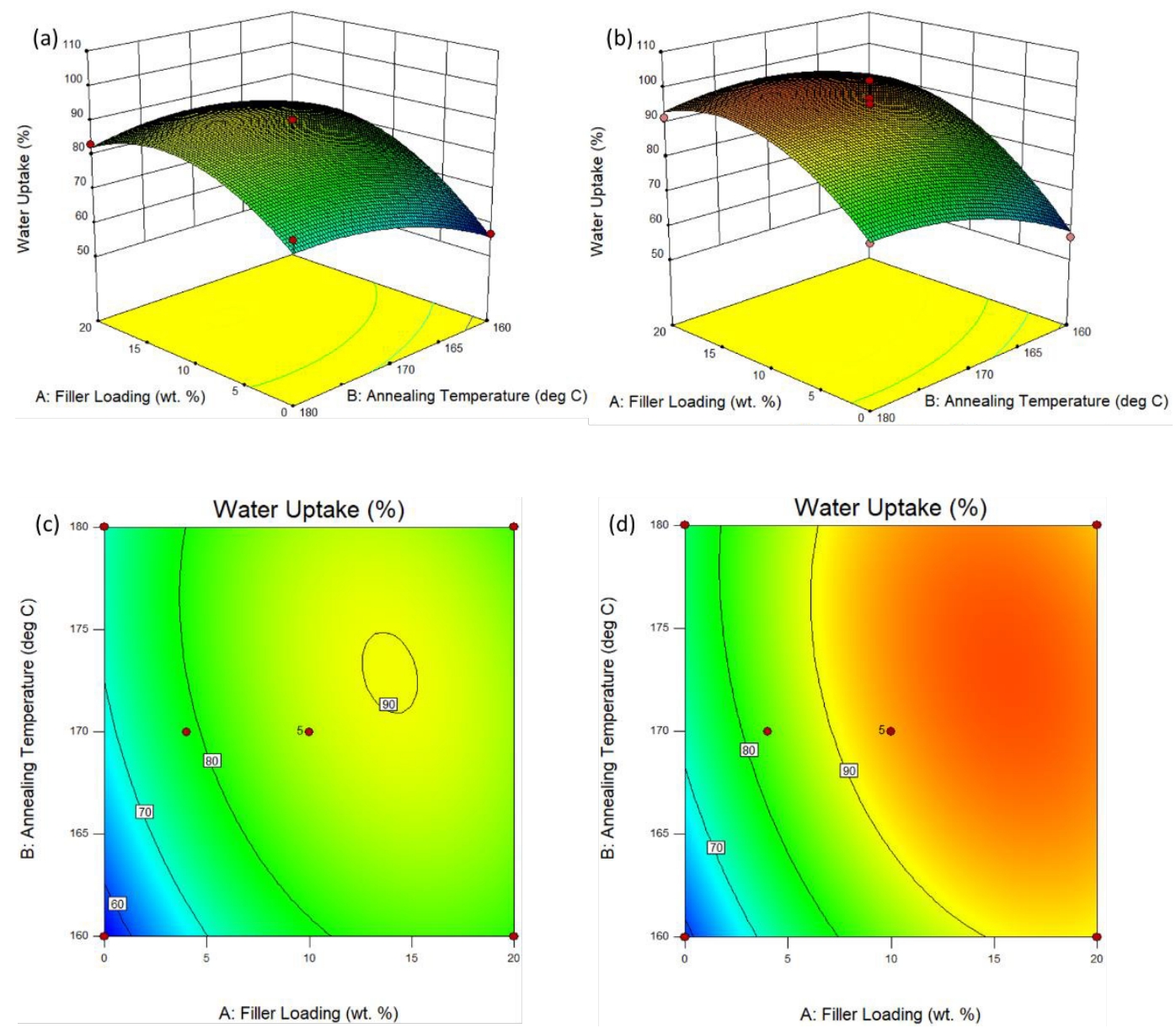

FIGURE 7. 3D-surface plots of (a) RHA (b) sRHA and 2D contour plots of (c) RHA (d) sRHA of the effect of filler loading and annealing temperature on water uptake

\section{EFFECTS OF FACTORS ON PROTON CONDUCTIVITY}

In Figure 8, both fillers showed a slightly different effect on the membrane proton conductivity. At constant annealing temperature, the proton conductivity of SPI/ RHA composite membranes increased from 5 to $12.5 \mathrm{wt}$. $\%$ whereas SPI/sRHA composite membranes increased from 7.5 to 15 wt. \%. Both types of filler experienced a drop in proton conductivity at an additional increase in filler loading. sRHA filler possessed a better distribution of particles in the SPI polymer matrix compared to RHA filler. RHA tended to agglomerate with each other when the loading of filler exceeded $12.5 \mathrm{wt}$ \%. Hence, an additional raise in filler loading led to more aggregations. High aggregation of filler particle caused the reduction of effective proton channels present in the composite membranes produced. sRHA had extra benefit compared to RHA as sRHA contained higher sulfonic acid group concentration. 

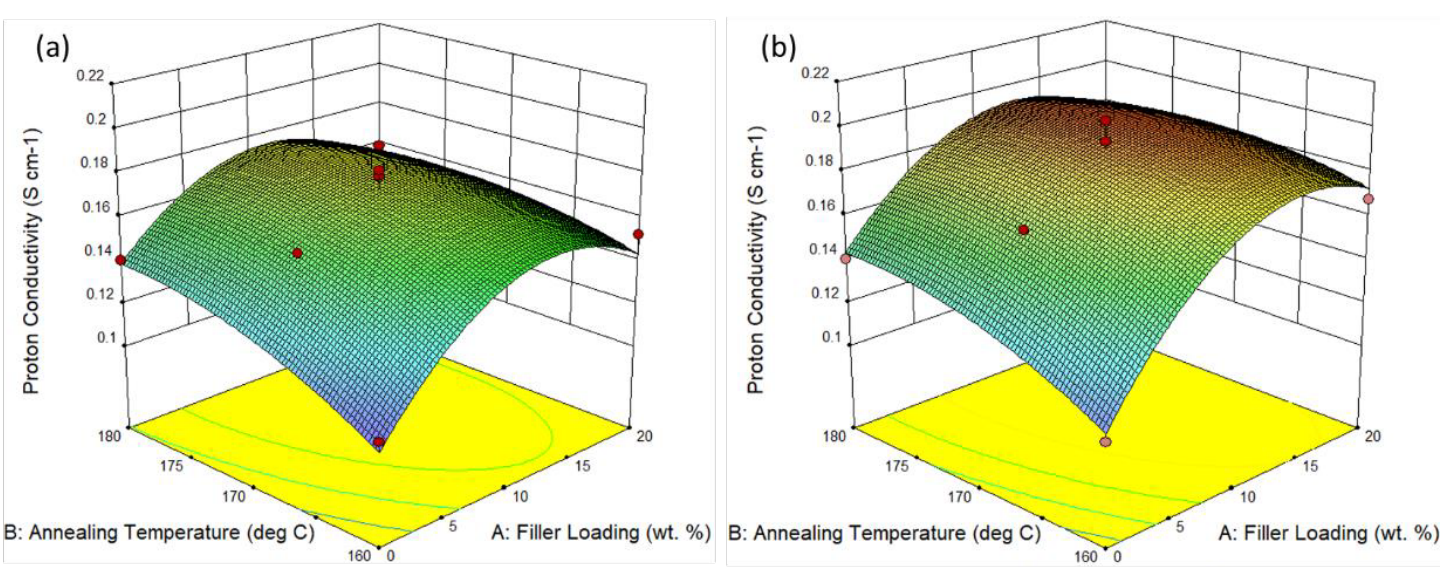

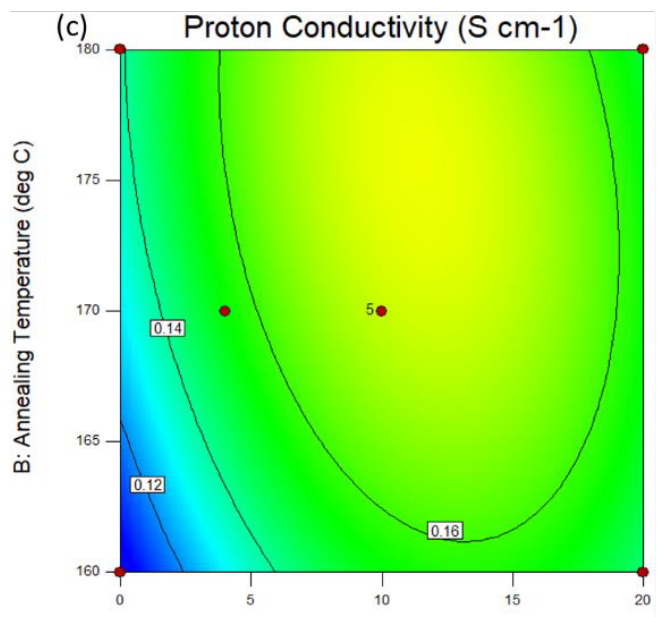

A: Filler Loading (wt. \%)

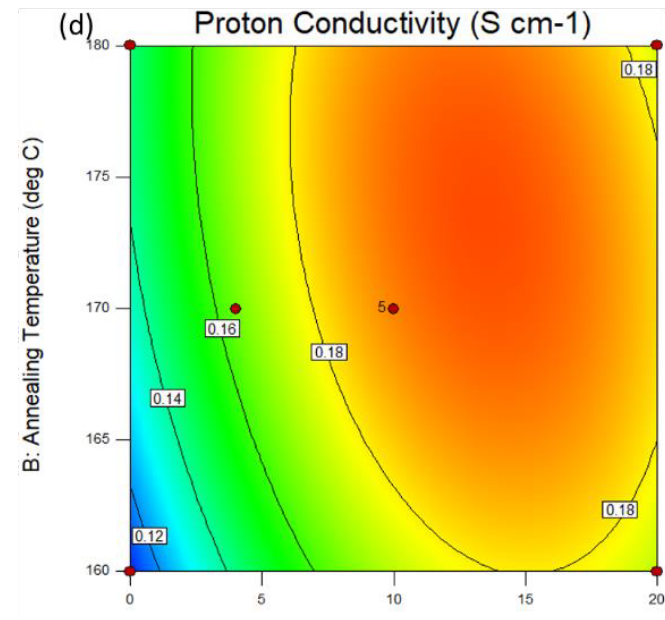

A: Filler Loading (wt. \%)

FIGURE 8. 3D-surface plots of (a) RHA (b) sRHA and 2D contour plots of (c) RHA (d) SRHA of the effect of filler loading and annealing temperature on proton conductivity

\section{EFFECTS OF FACTORS ON ION EXCHANGE CAPACITY}

IEC was defined as the number of the sulfonic acid group per $1 \mathrm{~g}$ of the membrane. Figure 9 shows that increased filler loading had led to a drop in IEC performance for both types of fillers. This was mainly due to the loss of sulfonic group in the polymer matrix when filler RHA or sRHA was incorporated into the membranes. Addition of filler into the polymer matrix had replaced out a part of the sulfonic acid groups from the composite membranes produced. Hence, IEC performance of the composite membranes reduced along with increased filler content. However, when comparing Figure 9(a) and Figure 9(b), it demonstrated that at the same filler loading, sRHA had a higher value of IEC compared to RHA. This was because sRHA had active participation in providing free acid groups to the membrane compared to RHA as sulfonation of rice husk ash added sulfonic acid groups into rice husk ash and hence, adding benefits to sRHA. Hence, composite membranes with sRHA had displayed higher IEC performance compared to that of RHA. 

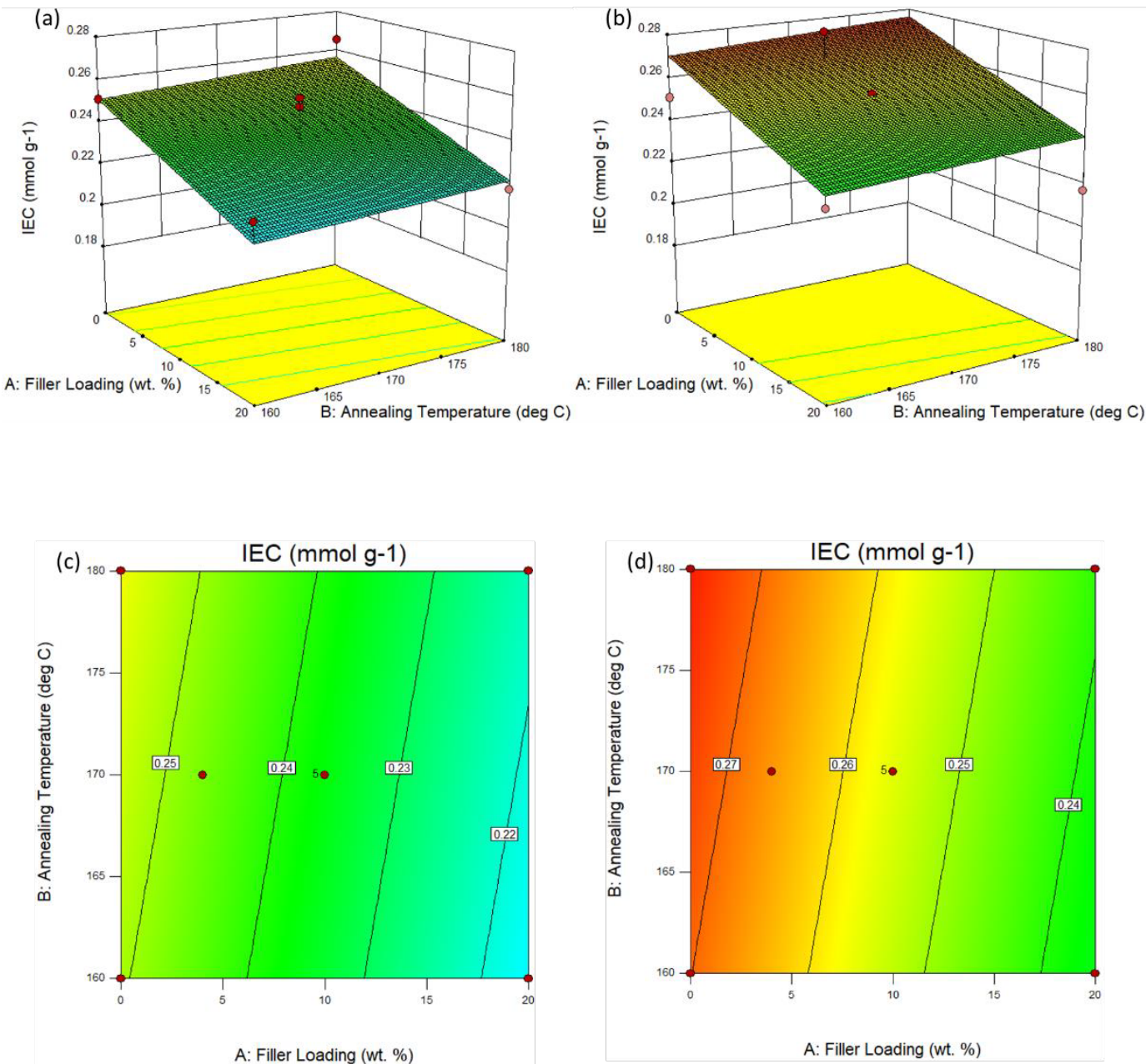

FIGURE 9. 3D-surface plots of (a) RHA (b) SRHA and 2D contour plots of (c) RHA (d) sRHA of the effect of filler loading and annealing temperature on IEC

\section{OPTIMIZATION AND CONFIRMATION}

In the process of optimization, the upper and lower limits of each synthesis parameter (filler loading, annealing temperature and types of filler) and its responses (water uptake, proton conductivity and ion exchange capacity), which were provided by the surface and contour plots, were used in the optimization procedure.

TABLE 7. The optimum conditions for highest physicochemical properties as suggested by Design Expert and validation experimental response values as confirmatory analysis

\begin{tabular}{lccc}
\hline & Suggested value & Experimental (Average) & Error (\%) \\
\hline Filler loading (wt.\%) & 11.5 & 11.5 & - \\
Annealing temperature $\left({ }^{\circ} \mathrm{C}\right)$ & 175 & 175 & - \\
Filler type & sRHA & sRHA & - \\
Water uptake (\%) & 97.04 & 90.97 & 6.26 \\
Proton conductivity $\left(\mathrm{S} \mathrm{cm}^{-1}\right)$ & 0.1946 & 0.1891 & 2.82 \\
IEC $\left(\mathrm{mmol} \mathrm{g}^{-1}\right)$ & 0.2547 & 0.2608 & 2.39 \\
\hline
\end{tabular}


Table 7 illustrated the possible solutions that fulfilled all the specified condition for the optimization of the physicochemical properties and values obtained experimentally. In this study, the optimum synthesis parameters in producing composite membrane SPI/ rice husk ash with the highest water uptake, proton conductivity, and ion exchange capacity are the composite membrane with the filler loading of $11.5 \mathrm{wt}$ \% of sRHA and produced at the annealing temperature of $175^{\circ} \mathrm{C}$. The optimized composite membrane produced under these three combinations of the synthesis parameter was renamed as S-12-sR in the next section. Experimental validation of these optimum values was repeated 3 times to obtain the average of the physicochemical properties response values. The samples for the validation experiment were prepared using the same procedure as optimization sample.

The physicochemical performances were examined under the same method as the optimization sample. The average values of water uptake, proton conductivity and IEC for the validation test were $90.97 \%, 0.1891$
$\mathrm{S} \mathrm{cm}^{-1}$ and $0.2608 \mathrm{mmol} \mathrm{g}^{-1}$, respectively. The error between the predicted and experimental values for water uptake, proton conductivity and IEC were $6.26,2.82$, and $2.39 \%$, respectively. These small error values proved that the three selected factors (filler loading, annealing temperature and filler type) could be used to maximizing the physicochemical performance of the composite membranes produced.

\section{PASSIVE SINGLE CELL PERFORMANCE}

The optimized composite membrane SPI/sRHA was tested using a passive single cell to investigate its DMFC performance. Figure 10 illustrates the power density and polarization curves of the optimized SPI/sRHA (S-12-sR) composite membrane, pristine SPI and Nafion 117 membranes. In Figure 10, it showed that under the optimized synthesis conditions, S-12-sR composite membrane outperformed the pristine SPI by giving the highest passive single DMFC maximum power density, which was $16.4 \mathrm{~mW} \mathrm{~cm}^{-2}$. This value was the two-fold of the pure SPI membrane $\left(8.1 \mathrm{~mW} \mathrm{~cm}^{-2}\right)$.

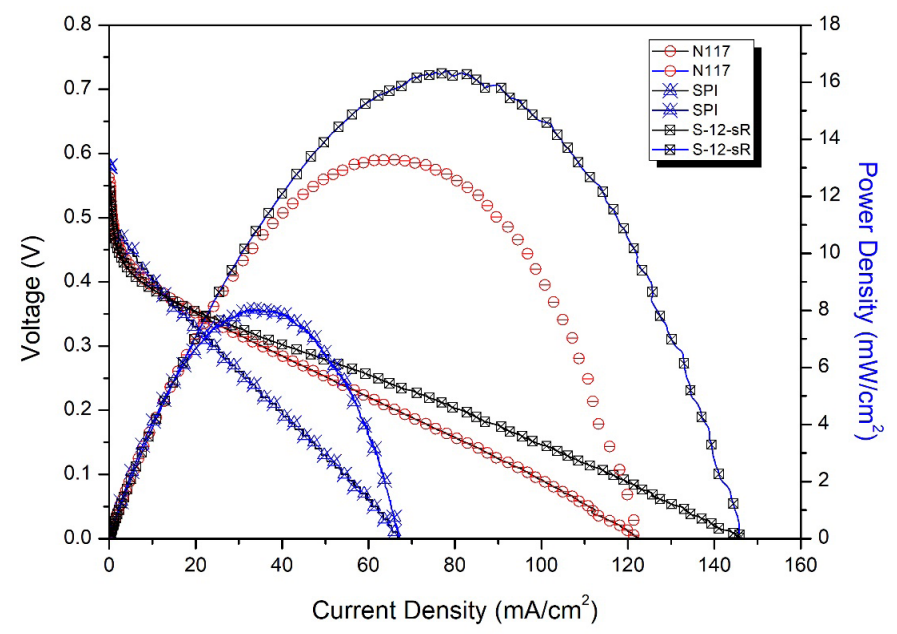

FIGURE 10. Polarization and power density curves of optimized S-12sR composite membrane, pure SPI membrane and commercial Nafion 117 membrane using $2 \mathrm{M}$ methanol solution at room temperature

The presence of sRHA in SPI polymer matrix had improved the membrane performances in term of water intake, proton conductivity and IEC. These physicochemical properties enabled the optimized membrane to have high water uptake, enhanced proton conductivity and improved IEC performances. Hence, with the optimum amount of sRHA added, it intensified the passive single cell performance. Besides that, the optimized SPI/sRHA composite membrane displayed $23.31 \%$ higher in the value of maximum power density as compared to commercial 
Nafion 117 membrane, which was only $13.3 \mathrm{~mW} \mathrm{~cm}^{-2}$ in this work. Nafion 117 was always facing the challenge of low tolerance in methanol crossover. The incorporation of sRHA in SPI matrix helped the optimized S-12-sR composite membrane to have low methanol permeability as rice husk ash blocked the methanol transport via the ionic channels present in the membrane matrix. Hence, it proved that with the enhanced physicochemical properties of the optimized S-12-sR membrane, the optimization of the filler loading, annealing temperature and filler type will give the highest performance of passive DMFC.

\section{CONCLUSION}

In summary, the optimized S-12-sR composite membrane had achieved higher fuel cell performance as compared to pristine SPI membrane and Nafion 117, which was the main objective for this work. This work is significant, as no work has been reported on incorporating modified RHA as filler in SPI matrix for DMFC application yet. The synthesis parameters such as loading of filler, annealing temperature and the types of filler used were chosen as the input variables and the physicochemical properties of the composite membrane produced such as water uptake, proton conductivity and ion exchange capacity were selected as the outputs or responses. Optimization using CCD in RSM had resulted in second-order quadratic models. These models had illustrated a good correlation between the predicted and the experimental results. The best-optimized composite membrane was S-12-sR, where it was fabricated with $11.5 \mathrm{wt}$ \% of sRHA under 175 ${ }^{\circ} \mathrm{C}$ of annealing temperature. S-12-sR showed the highest value of physicochemical performance, which were $90.97 \%, 0.1891 \mathrm{~S} \mathrm{~cm}^{-1}$, and $0.2608 \mathrm{mmol} \mathrm{g}^{-1}$ for water uptake, proton conductivity and IEC, respectively, with an average error below 5\%. The maximum power density obtained in the passive single DMFC test for S-12-sR was $16.4 \mathrm{~mW} \mathrm{~cm}^{-2}$, which was $23.31 \%$ higher than Nafion 117 . Tables 8 and 9 summarises the comparison of membrane performance and passive DMFC single cell performance of the current work and other recent researches. Hence, it proved that through optimization, high performance of composite membrane S-12-sR can be obtained and sulfonation of RHA had increased the potential to replace the silica in DMFC applications. As future prospects, other types of modifications on RHA such as functionalized RHA with different types of chemicals should be carried out to investigate the relationship between the functionalized RHA and the fuel cell performance.

TABLE 8. Comparison of membrane performance in term of IEC, water uptake and proton conductivity for this work and other recent researches

\begin{tabular}{|c|c|c|c|c|}
\hline Membrane / Filler & Water uptake (\%) & $\begin{array}{l}\text { Proton conductivity } \\
\qquad(\mathrm{S} / \mathrm{cm})\end{array}$ & IEC $(\mathrm{mmol} / \mathrm{g})$ & References \\
\hline S-12-sR & 90.97 & 0.1891 & 0.2608 & This work \\
\hline Nafion 115 & 19 & 0.0312 & 0.81 & (Kumar et al. 2016) \\
\hline Nafion 117 & 35 & 0.096 & 0.91 & (You et al. 2019) \\
\hline Nafion/0.8Pt-TiO $2 / 0.2 \mathrm{GO}$ & 36 & 0.110 & 0.98 & (Yang et al. 2016) \\
\hline Chitosan/silica & 80 & 0.009 & 0.52 & $\begin{array}{c}\text { (Vijayakumar et al. } \\
\text { 2018a) }\end{array}$ \\
\hline Chitosan-PAni/ $\mathrm{SiO}_{2}$ & 60 & 0.008 & 0.96 & $\begin{array}{c}\text { (Vijayakumar et al. } \\
2018 b \text { ) }\end{array}$ \\
\hline Poly(ethyleneimine) $/ \mathrm{SiO}_{2}$ & 68.95 & 0.079 & 2.36 & $\begin{array}{c}\text { (Pandey \& Shahi } \\
\text { 2015) }\end{array}$ \\
\hline $\mathrm{PVA} / \mathrm{SiO}_{2}$ & 60 & 0.011 & 0.69 & $\begin{array}{c}\text { (Shahabadi et al. } \\
\text { 2015) }\end{array}$ \\
\hline SPPS/PWA/Silica & 38.6 & 0.101 & 1.39 & (Devrim 2014) \\
\hline Nafion/Pd-SiO ${ }_{2}$ & 44.9 & 0.129 & 0.86 & (Thiam et al. 2013) \\
\hline
\end{tabular}


TABLE 9. Comparison of passive DMFC single cell performance for this work and other recent researches

\begin{tabular}{|c|c|c|c|c|c|c|c|}
\hline \multirow[b]{2}{*}{ Membrane } & \multirow[b]{2}{*}{ DMFC type } & \multirow[b]{2}{*}{ Anode } & \multirow[b]{2}{*}{ Cathode } & \multicolumn{2}{|c|}{ Operational parameters } & \multirow[b]{2}{*}{$\begin{array}{c}\text { MPD } \\
\left(\mathrm{mW} \mathrm{cm}^{-2}\right)\end{array}$} & \multirow[b]{2}{*}{ References } \\
\hline & & & & $\begin{array}{c}\mathrm{MeOH} \\
\text { Conc. (M) }\end{array}$ & $\begin{array}{c}\text { Operational } \\
\mathrm{T}\left({ }^{\circ} \mathrm{C}\right)\end{array}$ & & \\
\hline S-12-sR & Passive & $\mathrm{Pt} / \mathrm{Ru}$ & $\mathrm{Pt}$ & 2 & RT & 16.4 & This work \\
\hline Pure SPI & Passive & $\mathrm{Pt} / \mathrm{Ru}$ & $\mathrm{Pt}$ & 2 & RT & 8.1 & This work \\
\hline Nafion 117 & Passive & $\mathrm{Pt} / \mathrm{Ru}$ & $\mathrm{Pt}$ & 2 & RT & 13.3 & This work \\
\hline Nafion 115 & Passive & $\mathrm{Pt} / \mathrm{Ru}$ & $\mathrm{Pt}$ & 8 & 25 & 11 & (Chen et al. 2017 \\
\hline SPI-15-RHA & Passive & $\mathrm{Pt} / \mathrm{Ru}$ & $\mathrm{Pt}$ & 2 & RT & 13 & (You et al. 2019) \\
\hline $\mathrm{SPI}-\mathrm{SiO}_{2}$ & Passive & $\mathrm{Pt} / \mathrm{Ru}$ & $\mathrm{Pt}$ & 3 & 25 & 7.3 & (Lee et al. 2008) \\
\hline $\begin{array}{l}\text { Nafion/Pd- } \\
\mathrm{SiO}_{2}\end{array}$ & Passive & $\mathrm{Pt} / \mathrm{Ru}$ & $\mathrm{Pt}$ & 2 & RT & 10.4 & $\begin{array}{c}\text { (Thiam et al. } \\
\text { 2013) }\end{array}$ \\
\hline $\begin{array}{l}\text { Nafion 117/ } \\
\text { GC-500 }\end{array}$ & Passive & $\mathrm{Pt} / \mathrm{Ru}$ & $\mathrm{Pt}$ & 3 & RT & 13.7 & $\begin{array}{c}\text { (Ong et al. } \\
2017 b)\end{array}$ \\
\hline $\begin{array}{l}\text { Sodium } \\
\text { alginate/SGO }\end{array}$ & Passive & $\mathrm{Pt} / \mathrm{Ru}$ & $\mathrm{Pt}$ & 2 & RT & 13.6 & $\begin{array}{c}\text { (Shaari \& } \\
\text { Kamarudin } \\
\text { 2018) }\end{array}$ \\
\hline
\end{tabular}

* MPD: Maximum power density

* RT: Room temperature

\section{ACKNOWLEDGEMENTS}

The authors appreciatively acknowledge the financial support given by Universiti Kebangsaan Malaysia (UKM) under PP-SELFUEL-2020.

\section{REFERENCES}

Abdullah, N. \& Kamarudin, S.K. 2015. Titanium dioxide in fuel cell technology: An overview. Journal of Power Sources 278: 109-118.

Awang, N., Jaafar, J. \& Ismail, A.F. 2018. Thermal stability and water content study of void-free electrospun SPEEK/ cloisite membrane for direct methanol fuel cell application. Polymers 10(2): 194-209.

Azat, S., Korobeinyk, A.V., Moustakas, K. \& Inglezakis, V.J. 2019. Sustainable production of pure silica from rice husk waste in Kazakhstan. Journal of Cleaner Production 217: 352-359.

Barbosa, S.L., Ottone, M., De Almeida, M.T., Lage, G.L.C., Almeida, M.A.R., Nelson, D.L., Dos Santos, W.T.P., Clososki, G.C., Lopes, N.P., Klein, S.I. \& Zanatta, L.D. 2018. Ketalization of ketones to 1,3-dioxolanes and concurring self-aldolization catalyzed by an amorphous, hydrophilic $\mathrm{SiO}_{2}-\mathrm{SO}_{3} \mathrm{H}$ catalyst under microwave irradiation. Journal of the Brazilian Chemical Society 29(8): 1663-1671.

Chen, W., Yuan, W., Ye, G., Han, F. \& Tang, Y. 2017. Utilization and positive effects of produced $\mathrm{CO}_{2}$ on the performance of a passive direct methanol fuel cell with a composite anode structure. International Journal of Hydrogen Energy 42(23): 15613-15622.
Cui, Y., Liu, Y., Wu, J., Zhang, F., Baker, A.P., Lavorgna, M., Wu, Q., Tang, Q., Lu, J., Xiao, Z. \& Liu, X. 2018. Porous silicon-aluminium oxide particles functionalized with acid moieties: An innovative filler for enhanced Nafion-based membranes of direct methanol fuel cell. Journal of Power Sources 403: 118-126.

Devrim, Y. 2014. Fabrication and performance evaluation of hybrid membrane based on a sulfonated polyphenyl sulfone/ phosphotungstic acid/silica for proton exchange membrane fuel cell at low humidity conditions. Electrochimica Acta 146: 741-751.

Ekrami-Kakhki, M.S., Naeimi, A. \& Donyagard, F. 2019. Pt nanoparticles supported on a novel electrospun polyvinyl alcohol-CuOCo $\mathrm{O}_{4}$ /chitosan based on Sesbania sesban plant as an electrocatalyst for direct methanol fuel cells. International Journal of Hydrogen Energy 44(3): 1671-1685.

Fadzillah, D.M., Kamarudin, S.K., Zainoodin, M.A. \& Masdar, M.S. 2019. Critical challenges in the system development of direct alcohol fuel cells as portable power supplies: An overview. International Journal of Hydrogen Energy 44(5): 3031-3054.

Johánek, V., Ostroverkh, A. \& Fiala, R. 2019. Vapor-feed low temperature direct methanol fuel cell with $\mathrm{Pt}$ and PtRu electrodes: Chemistry insight. Renewable Energy 138: 409-415.

Kumar, V., Kumar, P., Nandy, A. \& Kundu, P.P. 2016. A nanocomposite membrane composed of incorporated nanoalumina within sulfonated PVDF-co-HFP/Nafion blend as separating barrier in a single chambered microbial fuel cell. RSC Advances 6(28): 23571-23580. 
Kuo, Y.J. \& Lin, H.L. 2018. Effects of mesoporous fillers on properties of polybenzimidazole composite membranes for high-temperature polymer fuel cells. International Journal of Hydrogen Energy 43(9): 4448-4457.

Lee, C.H., Park, C.H., Lee, S.Y., Jung, B.O. \& Lee, M.L. 2008. Passive DMFC system using a proton conductive hydrocarbon membrane. Desalination 233(1): 210-217.

Li, J., Xu, G., Luo, X., Xiong, J., Liu, Z. \& Cai, W. 2018. Effect of nano-size of functionalized silica on overall performance of swelling-filling modified Nafion membrane for direct methanol fuel cell application. Applied Energy 213: 408-414.

Liu, D., Peng, J., Li, Z., Liu, B. \& Wang, L. 2018. Improvement in the mechanical properties, proton conductivity, and methanol resistance of highly branched sulfonated poly(arylene ether)/graphene oxide grafted with flexible alkylsulfonated side chains nanocomposite membranes. Journal of Power Sources 378: 451-459.

Ong, B.C., Kamarudin, S.K. \& Basri, S. 2017a. Direct liquid fuel cells: A review. International Journal of Hydrogen Energy 42(15): 10142-10157.

Ong, B.C., Kamarudin, S.K., Masdar, M.S. \& Hasran, U.A. 2017b. Applications of graphene nano-sheets as anode diffusion layers in passive direct methanol fuel cells (DMFC). International Journal of Hydrogen Energy 42(14): 92529261.

Pandey, R.P. \& Shahi, V.K. 2015. Phosphonic acid grafted poly(ethyleneimine)-silica composite polymer electrolyte membranes by epoxide ring opening: Improved conductivity and water retention at high temperature. International Journal of Hydrogen Energy 40(41): 1423514245.

Parthiban, V., Panda, S.K. \& Sahu, A.K. 2018. Highly fluorescent carbon quantum dots-Nafion as proton selective hybrid membrane for direct methanol fuel cells. Electrochimica Acta 292: 855-864.

Saccà, A., Carbone, A., Gatto, I., Pedicini, R. \& Passalacqua, E. 2018. Synthesized yttria stabilised zirconia as filler in proton exchange membranes (PEMs) with enhanced stability. Polymer Testing 65: 322-330.

Salim, Z.A.S.A., Hassan, A. \& Ismail, H. 2018. The effect of high purity rice husk silica synthesised using solvent-thermal extraction method on the properties of natural rubber compounds. BioResources 13(3): 6936-6951.

Shaari, N. \& Kamarudin, S.K. 2018. Performance of crosslinked sodium alginate/sulfonated graphene oxide as polymer electrolyte membrane in DMFC application: RSM optimization approach. International Journal of Hydrogen Energy 43(51): 22986-23003.

Shahabadi, R., Abdollahi, M. \& Sharif, A. 2015. Preparation, characterization and properties of polymer electrolyte nanocomposite membranes containing silica nanoparticles modified via surface-initiated atom transfer radical polymerization. International Journal of Hydrogen Energy 40(9): 3749-3761.
Thiam, H.S., Daud, W.R.W., Kamarudin, S.K., Mohamad, A.B., Kadhum, A.A.H., Loh, K.S. \& Majlan, E.H. 2013. Performance of direct methanol fuel cell with a palladiumsilica nanofibre/Nafion composite membrane. Energy Conversion and Management 75: 718-726.

Vijayakumar, V. \& Khastgir, D. 2018a. Fabrication and comprehensive investigation of physicochemical and electrochemical properties of chitosan-silica supported silicotungstic acid nanocomposite membranes for fuel cell applications. Energy 142: 313-330.

Vijayakumar, V. \& Khastgir, D. 2018b. Hybrid composite membranes of chitosan/sulfonated polyaniline/silica as polymer electrolyte membrane for fuel cells. Carbohydrate Polymers 179: 152-163.

Wang, H., Li, X., Feng, X., Liu, Y., Kang, W., Xu, X., Zhuang, X. \& Cheng, B. 2018. Novel proton-conductive nanochannel membranes with modified $\mathrm{SiO}_{2}$ nanospheres for direct methanol fuel cells. Journal of Solid State Electrochemistry 22(11): 3475-3484.

Yang, H.N., Lee, W.H., Choi, B.S. \& Kim, W.J. 2016. Preparation of Nafion/Pt-containing $\mathrm{TiO}_{2} /$ graphene oxide composite membranes for self-humidifying proton exchange membrane fuel cell. Journal of Membrane Science 504: 20-28.

Ying, Y.P., Kamarudin, S.K. \& Masdar, M.S. 2018. Silicarelated membranes in fuel cell applications: An overview. International Journal of Hydrogen Energy 43(33): 1606816084.

You, P.Y., Kamarudin, S.K. \& Masdar, M.S. 2019. Improved performance of sulfonated polyimide composite membranes with rice husk ash as a bio-filler for application in direct methanol fuel cells. International Journal of Hydrogen Energy 44(3): 1857-1866.

Zainoodin, A.M., Kamarudin, S.K., Masdar, M.S., Daud, W.R.W., Mohamad, A.B. \& Sahari, J. 2014. Investigation of MEA degradation in a passive direct methanol fuel cell under different modes of operation. Applied Energy 135: 364-372.

You Po Ying, Siti Kartom Kamarudin, Mohd Shahbudin Masdar \& Azran Mohd Zainoodin*

Fuel Cell Institute

Universiti Kebangsaan Malaysia

43600 UKM Bangi, Selangor Darul Ehsan

Malaysia

Siti Kartom Kamarudin \& Mohd Shahbudin Masdar Research Centre for Sustainable Process Technology Faculty of Engineering and Built Environment

Universiti Kebangsaan Malaysia

43600 UKM Bangi, Selangor Darul Ehsan

Malaysia

*Corresponding author; email: azrans@ukm.edu.my

Received: 6 August 2020

Accepted: 11 September 2020 